\title{
Empowering College Student Writers Through Collaboration
}

\section{A. Chaedar Alwasilah \\ Universitas Pendidikan Indonesia, Bandung}

\begin{abstract}
This study aimns at describing the effectiveness of collaborative writing as perceived by students of writing course at a university level. This study also aimns at describing the effectiveness of collaborative writing compared with the common practice of writing in high schools. Two groups of students were involved. They were asked to read an opinion article from newspaper published in Indonesia and to critique it in Indonesian. The results show that the respondents are likely to appreciate the experience of multiple drafting. The students' writing become not mere assigments, but the heart and soul of the entire term. As an implication of this study, it is suggested that the students be considered as apprentice writers filled with potential in the process of collaborative writing.
\end{abstract}

Keywords: collaboration, collaborative writing

The objectives of CUE and CUI vary from college to college across Indonesia, yet in general they are aimed at developing reading skills. At ITB (Bandung Institute of Technology), for example, CUE sets the following as the curricular objective:

To provide the students with effective reading skills, such as skill to anticipate reading content, to look for certain information, to identify major and supporting ideas in a paragraph, to speculate upcoming ideas, to guess the meaning of a word, and to be familiar with different patterns of paragraphing.

Meanwhile, CUI sets the following as its curricular objective:

To provide the students with writing skills. The course materials include genres of science and technology, spelling, word formation, syntax, terminology, definition, syllogism, discourse, paragraphing, technical writings, rhetoric, speech delivery, and how to conduct seminar. 
The objectives above relatively represent the curricular objectives of CUE and CUI courses all over Indonesia, where reading is emphasized in CUE and writing in CUI. It is reasonable to expect Indonesian college graduates to demonstrate a reasonable degree of reading proficiency in English and writing productivity in Indonesian. To our chagrin, that is not the case. Numerous studies affirm the assumption that both CUE and CUI have been a failure.

Alwasilah (1994) in his study involving 131 college students in Bandung reported that $65.8 \%$ of the respondent were disappointed with the CUE, where:

- The majority of respondents $(56.8 \%)$ were not informed about the syllabus of CUE.

- Most lecturers (60.4\%) provided no consultation services.

- Most lecturers (63.1\%) did not administer any diagnostic tests

A need analysis by Alwasilah (1997) involving 89 students of Universitas Pendidikan Indonesia revealed more or less the same CUI materials, namely spelling, punctuation; grammar (effective sentences, ineffective sentences, standard and substandard sentences); and patterns of paragraphing. All of these were perceived by most respondents $(93.25 \%)$ as "nothing new" subjects-a repetition of high school subjects. The respondents recommended the following subjects (see Table 1) to be included in CUI.

Table 1 Student-recommended materials for CUI

\begin{tabular}{lll}
\hline Subject for CUI & Percentage & of respondents (\%) \\
\hline Writing & $65.16 \%$ \\
1. $\quad$ Papers & $79.77 \%$ \\
2. & Research proposal & $74.15 \%$ \\
3. & Scientific writing & $71.91 \%$ \\
4. & Book or chapter report & $64.04 \%$ \\
5. & Paragraph development & $58.42 \%$ \\
6. & Book review & $49.43 \%$ \\
7. & Opinion article for mass media & $49.43 \%$ \\
Reading & $57.30 \%$ \\
1. $\quad$ Fast and effective reading & $62.93 \%$ \\
2. & Reading scientific writing & $52.80 \%$ \\
\hline
\end{tabular}

\begin{tabular}{|c|c|c|}
\hline Subject for CUI & Percentage & of respondents (\%) \\
\hline Speaking & & $47.19 \%$ \\
\hline 1. How to hold a seminar & & $60.67 \%$ \\
\hline $\begin{array}{l}2 . \quad \text { Speech delivery } \\
\text { Listening }\end{array}$ & & $\begin{array}{l}50.56 \% \\
40.44 \%\end{array}$ \\
\hline
\end{tabular}

The table above shows that writing should take precedence over the other language skills in developing CUI syllabi. Meanwhile CUE should concentrate on developing reading skills. Students should be encouraged to be avid readers and productive writers at the same time.

\section{INSIGHTS FROM THE LTTERATURE}

From his longitudinal study involving 100 college freshmen representing different high schools in West Java and its vicinity, Alwasilah (1999) concludes the following:

1. Writing has been the most neglected subject in high schools.

2. Writing is the most difficult language skill to acquire by students and to teach by teachers.

3. High school students as well as college students have been subjected to inexperienced teachers or professors.

4. Writing classes are dominated by discussion on grammar and theories of writing with less exposure to the practice of writing.

5. In most cases, student's writings are not corrected or returned to the students.

6. The most effective and the only way of teaching writing is through the practice of writing.

A commonly complained problem in writing classes is the class size of 40 to 80 people which makes it impossible for instructors to read and correct all students' work. The question then is how to design a writing workshop for big classes; and that is the issue this paper attempts to address. From my experience, I found collaborative writing most efficient and pragmatic in coping with big classes of undergraduate students.

Collaborative writing offers us the following benefits:

- It fosters cooperation and tolerance of other's opinion and increases their ability to formulate and articulate ideas, "calling on their own resources for creative or analytical thought rather than merely on their capacity for data acquisition and restatement" (Schenck 1986:9). 
- It helps students to view writing as a process because group work emphasizes revision, allows students to teach their peers, and allows weaker students to see the writing of their more able classmates (Lunsford 1986).

- It encourages students to learn from one another when they work together; and offers experience in an environment similar to the one they are likely to find in the professional world (Allen:1986).

- It promotes self-correction and multiple drafting, where the writer becomes his or her own best reader. It suggests that, “... after any particular draft of writing, the writer becomes an imaginary reader, and the draft becomes an external object." (Brookes and Grundy 1990:21).

- In conclusion, "collaborative writing essentially a social process through which writers looked for areas of shared understanding. To reach such an understanding, participants functioned according to several social and interactional rules; they set a common goal; they had differential knowledge; they interacted as a group; and they distanced themselves from the text." (Murray, 1992:102)

From her research on collaborative learning, Fox (1999) testified that the practical assistance given in terms of models, consultation, checking of work in progress, mini exercises in class, feedback, and other provision of structure have enabled the students to move more comfortably towards autonomy in their learning. My earlier study (Alwasilah:1999b) involving 30 graduate students on collaborative writing revealed the following characteristics:

- It makes students aware of the complexity of writing processes and of their weaknesses.

- As a strategy of teaching, it can be applied at educational levels from elementary school to college.

- It motivates students to write, to learn how others write, and read more references.

- It is time consuming both for instructors and students.

- It is not easy to get peers who can work cooperatively.

- Peer suggestions allow too many alternatives.

Despite of some weaknesses above, collaborative writing was responded positively and favorably by most respondents. One of the respondents had the following to say about my writing class:

"When I was an undergraduate student my composition was always the best and I was satisfied with it. Now in your class, where my work is corrected, I come to realize my own weaknesses... This is an innovation. In my previous classes the instructors never wrote themselves. So what can you expect from their students? What they taught me was just a theory of writing. I'll give my students rewards as you do."

\section{METHODOLOGY}

The study reported here is a follow-up to the study on collaborative writing with the focus on writer responses to the professor comments and peer comments on the compositions (Alwasilah:1999b). The focus of the present study is on effectiveness of small group collaboration. The objectives of the study are as follows:

1. To describe the effectiveness of collaborative writing as perceived by the participants in terms of readiness for writing and acquired competence.

2. To describe the effectiveness of collaborative writing as compared with the common practice of writing in high schools.

3. To describe what the respondents did as a follow-up to the peer collaboration, professor-student conferences, and the improvement they made.

4. To propose a technique of evaluating student writing in collaborative classes.

\section{PARTICIPANTS IN THE STUOY}

The respondents were two groups consisting of 54 and 62 students taking my Writing I class at a private university in Bandung. They fairly represent various high schools in West Java and its vicinity. Writing I is a required course for English majors and is designed to provide students with basic skills of writing in English. The students are adult learners with elementary English proficiency who were subjected to unprofessional writing teachers in their high schools. What so called "writing class" was dominated by teachers" explanation about grammar, vocabulary, and theories about writing. In most cases, students' work was not corrected or returned to the students.

\section{PROCEDURE}

The respondent were asked to read an opinion article published in an Indonesian newspaper and to critique it in Indonesian. Their critique 
essays ranged from one to two pages, double space typed. This published article has a double function: (1) to introduce students to the published work, a stimulating authentic writing-something that they may want to accomplish in the future, and (2) to be a definite content of the writing, "for it provides much-needed intellectual stimulation and makes the course potentially as interesting and challenging as any academic course" (Schenck, 1986:84)

The class was split up into small groups of 5-6 students. Each student in the group was asked to read and give written comments on the others' rough drafts with the focus on certain aspects of composition such as mechanics and spelling. At the end of the session, all the drafts were commented on by all the members in the group. For the homework, the respondents had to rewrite the rough drafts, while taking peer comments, corrections, and suggestions into consideration. In the following week, the students were asked to do the same in a different group with the focus on different aspect of composition. The instructor researcher had to circulate in the class, moving from one group to another to monitor the collaboration.

By mid-semester, the students had to submit all the five drafts, including the finished work. They were also asked to write self evaluation and reflection on the course by answering to the guiding question prepared by the researcher. One of the questions went: "Do you think you learned a lot in this class?" All the rough drafts and finished work were graded and returned to the students. In the second half of the semester, the students did the same thing. The only difference was that they had to write an essay in English - a reaction essay on a selected article published in an English newspaper. For the final tests, the students had to submit all the 10 rough drafts, both Indonesian and English drafts, and to write another self evaluation and reflectio in Indonesian.

\section{ANALYSIS}

There are three categories of data collected in this study: (1) respondents' responses to the items of the questionnaires administered at the end of semester, (2) students' self evaluation and reflection on the course, and (3) multiple drafts produced during the whole semester (July to December 1999).

- Effectiveness of collaborative writing in terms of readiness for writing and acquired competence
Readiness for writing is respondents' psychological disposition for accomplishing a writing task. Table 1 shows degree of readiness as perceived by the respondents for writing before and after joining the workshop. Besides, the respondents felt they had potential to write.

Table 1 Perceived Readiness for Accomplishing Writing Tasks Before and After Joining the Workshop

\begin{tabular}{lll}
\hline Statement & Before & After \\
\hline You have competence to write. & $22.6 \%$ & $62.4 \%$ \\
Writing is simple for you. & $30.1 \%$ & $11.8 \%$ \\
Writing is difficult for you. & $30.1 \%$ & $66.7 \%$ \\
\hline
\end{tabular}

- Effectiveness of collaborative writing as compared with the common practice of writing in high schools

The effectiveness of collaboration is dependent on respondents" attitude towards the group and the situation created by it. Table 2 shows the respondents' attitude toward collaborative writing.

Table 2 'Respondent' Attitude Towards Collaboration

\begin{tabular}{lc}
\hline \multicolumn{1}{c}{ Statement } & Percentage of students \\
\hline You are pleased when working in group. & $64.5 \%$ \\
You are not pleased when working in group & $8.6 \%$ \\
You have learned a lot from the group. & $66.7 \%$ \\
Your writing improved. & $58.1 \%$ \\
You are now conscious of own weaknesses. & $76.3 \%$ \\
You are now open for others' suggestions. & $66.7 \%$ \\
The workshop can be applied at college. & $55.9 \%$ \\
The workshop can be applied in high schools. & $68.8 \%$ \\
Peer suggestions are confusing. & $59.1 \%$ \\
\hline
\end{tabular}

- Respondents' follow-up to the collaboration and the perceived improvement

Through mutual correcting, suggesting and multiple drafting, collaboration significantly improved students' writing as depicted in Table 3. Some aspects of writing improved more than others. 


\section{Table 3 Perceived Improvement on Respondents' Writing}

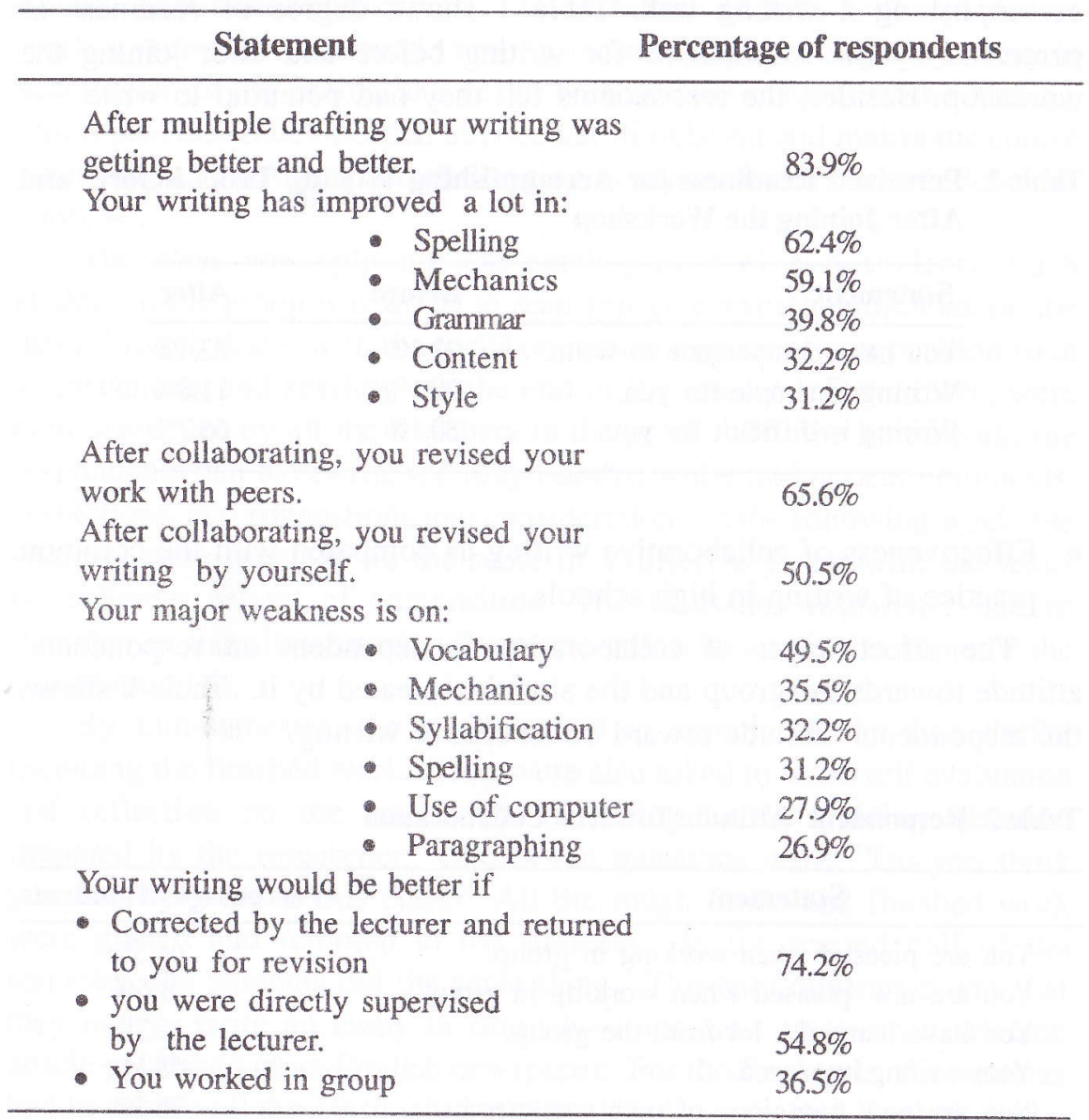

- Proposed technique of evaluating students' collaborative writing

In terms of evaluation, the respondents weighed aspects of writing differently. As Table 4 shows the process of rewriting of the drafts and grammar were weighed significantly by the respondents.

\section{Table 4 Perceived Importance of Composition Aspects for Evaluation}

\begin{tabular}{ll}
\hline Aspects of writing (class) & Percentage of Respondents \\
\hline $\begin{array}{l}\text { Evaluation of collaborative writing } \\
\text { should be based on: }\end{array}$ \\
The process of revision (multiple drafting) & $65.6 \%$ \\
- Final version after multiple drafting & $56.9 \%$ \\
- Class participation and frequency & $36.6 \%$ \\
The most important aspect to be evaluated & \\
by instructor is: & \\
- Grammar & $60.2 \%$ \\
- Mechanics & $56.9 \%$ \\
- Chelling & $56.9 \%$ \\
- Rhetoric & $38.7 \%$ \\
- Paragraph development & $37.6 \%$ \\
\hline
\end{tabular}

Reading thoroughly students'self evaluation and reflection, I found that their evaluation was consistent with virtually all findings solicited through the questionnaires. In other words, all the findings are well shared by the majority of the respondents. Students" self evaluation and reflection constitutes an authentic portfolio reflecting the writing competence of its writer. The students were encouraged to freely (some of them did emotionally) evaluate the course, the instructor, and all other aspects. All the rough drafts and the finished work were carefully documented, as they constitute authentic individual portfolios for evaluation. Over the semester, the students accumulated in their folders rough drafts full with peer comments, instructor comments, self reflections, and individual journals. Care was taken to notice the following aspects:

- number of rough drafts and finished work submitted;

- length of composition of the draft;

- quantity and quality of peer comments on the writing.

- number of peers consulted in the group;

- gradual improvement in all the drafts; and

- quantity of self-evaluation and reflection

All these components constitute what the respondents achieved in the whole semester. Tierney et al. affirm that "in reading and writing, this 
entails valuing process as well as achievements, and diversity as well as standards" (1991:49). They further elaborate three essentials of portfolios as follows:

- They are systematic collections serving as the basis to examine effort, process, improvement, and achievement.

- They represent activities and processes.

- They represent collective commitment to helping students become aware of their development as readers and writers. (Tierney et al. 1991:41).

\section{DISCUSSION}

\section{Indonesian First, English Second}

To teach writing skills I defend the idea of encouraging students to be proficient in Indonesian first before they learn how to write in English. We prepare our students to become citizens who will contribute to literacy development in their immediate environment. A theory exists that one's linguistic competence is transferable to another language. In Writing I, therefore, I use the first half of the semester to practice writing in Indonesian.

\section{Mechanies and Spelling}

As seen in Table 3, the respondents reported significant improvement in spelling and mechanics. These are the two aspects very much neglected by writing instructors in schools and colleges as well. Many emphasize the logic and content of writing, thus losing sight of the bases of writing. They have to be reviewed in college writing courses. In my experience, I need one semester to make the students aware of the spelling, punctuation, syllabification, page numbering, how to quote, how to write a bibliography, and even how to staple the papers. Good writing, I am convinced, begins with sustainable awareness of these "small" things!

\section{Reading-Writing Connection}

Writing presupposes reading, therefore they have to be integrated. Reading by default will never contribute to writing. In my observation, the common practice of reading instruction in high schools is designed with the following objectives: to understand the text $(64.5 \%)$, to report the passage orally $(39.7 \%)$, and last and the least to report in writing (26.9\%).
It is suggested that the instructors now turn to collaborative learning, in which, students are given multiple opportunities to interact with print, to choose the materials they read, to collaborate and communicate each other, to write often, to use literature for a variety of purposes, and to engage with assessment of their own progress (Tierney et.al., 1991:53).

In general, College Undergraduate English is aptly aimed at developing reading skills, however; it does not significantly contribute to writing. It would be challenging for students if they are assigned a text not for comprehension, but for written reproduction.

\section{Teachers' Comments Matter a Lot!}

The 1970's and 1980's brought a major change in approaching writing instruction. Quite the opposite, the emphasis is now on the process rather than the product of writing. Activities associated with process approaches include (1) brainstorming, (2) journal writing, (3) emphasizing students' ideas and experience, (4) small group activities, (5) teacher-student conferences, (6) multiple drafts, (7) postponing concern with editing skills until the final draft, and (8) deferring or eliminating grades - all of which are summarized as prewriting, drafting, revising, and editing (Langer and Applebee 1987:6) College Undergraduate English (CUE) and Indonesian (CUI) should not repeat the notorious practice of writing instruction where students' work is not commented on and returned to them. The fact that CUE and CUI classes are big classes should a good reason for instructors to turn to collaborative reading-writing.

\section{EVALUATION}

The respondents seemed to appreciate the experience of multiple drafting, from which they learned a great deal. Process is more important than product, "with the caveat that the processes are recursive rather than linear, complex rather than simple" (Langer and Applebee, 1987:6). Portfolios, accordingly, are to be viewed as evidences of students' achievement. These bring consequences on the teacher's part: collecting students' portfolios, reading through them, commenting on them, and most importantly returning them to the students for revision.

Table 4 shows how grammar, spelling, and mechanics were weighed by the respondents. Relatively speaking, mechanics and spellings are easy to correct. Students need to be taught to be careful and to be taught how 
to use the dictionary. As with English grammar, I am sure that grammar is to be learned along the way through writing and other courses. Grammar courses should be held responsible for providing students with internalized grammar. Teaching writing is not at all the same as teaching grammar. I agree with Ruszkiewicz when he says:

The writing produced by students in this kind of course-the essays, journals, research papers, themes, paragraphs-become not mere assignments turned in at regular intervals for a grade, but the heart and soul of the entire term. And students themselves should be treated not as grammatical and stylistic subversives who need to be brought into line for the good of civilization, but as apprentice writers filled with potential" (1986:80).

\section{PROPOSED COLLEGE UNDERGRADUATE WRTING (CUW)}

Throughout the paper I emphasize reading-writing connection and the importance of implementing the collaborative approach to CUW. Research shows that "activities involving writing lead to better learning than activities involving reading and studying only" (Langer and Applebee, 1987:135). Based on the previous discussions, I respectfully submit the following as a guideline.

- There is no need to add more credit hours for CUE or CUI, nor to postpone them till the seventh or eighth semester. What is urgent now is to maximize and reorient their function, namely to provide the students with writing skills in Indonesian. Despite its reading-based approach, CUE should be geared towards writing as the target skill. Thus, the name Creative Writing or College Composition (Menulis Kreatif or Komposisi Tingkat Universitas) sounds more authoritative and challenging, as it aptly reflects the intended mission.

College writing should empower the students. Empowerment realizes itself, among others, when ownership is established for example through subject-area writing and think papers, where students meaningfully explore and honestly share their specialization with others. Choosing topics with care will not only nurture the development of composing abilities, but it also assures ownership. Through exposure and practice, we are developing a community of new authors who are deliberately made to realize their complete potential.
- Ownership suggests empowerment and recognition. Students' portfolios should be recognized especially by the writing instructors. Marking papers, articles, think papers, poems, etc. is unavoidable. Commenting, congratulating, suggesting, and showing particular strengths of the paper significantly contribute to self-esteem, self-confidence, and selfactualization of the student writers. In other words, they help internalize ownership.

- I believe that self correction is preferable to peer correction, and peer correction is preferable to teacher correction. In collaborative writing, the teacher's role is that of "an enable of student self-discovery rather than that of instructor" (Brookes and Grundy 1990:53). Therefore, small group interaction is most obvious throughout collaborative writing.

- Finally mention should be made on the importance of needs analysis. CUE is based on the approach of ESP (English for Specific Purposes), whose major characteristic are as follows:

1. It is designed especially for adult learners who have acquired general English;

2. It is designed to provide students with specific skills to enable them to develop their profession, career, occupation and specialization.

3. It is usually designed for a group of homogenous learners.

In the Indonesian context, however, CUE and CUI classes are not necessarily homogenous. It is then necessary that needs analysis be conducted before designing any CUE, so that the courses meet the curricular objectives as quoted on the first page of this paper. Without such an analysis, CUE and CUI are just rituals like wayang kulit performance and sambutan pejabat (Coleman:1996).

\section{REFERENCES}

Allen, O. Jane. 1986. The Literature Major and Technical Writing. In Bridges, (Ed.), (69-77).

Alwasilah, A. Chaedar. 1994. Laporan Penelitian Profil Peserta Kursus Bahasa Inggris di Balai Bahasa IKIP Bandung. Bandung: Balai Bahasa IKIP Bandung.

Alwasilah, A. Chaedar. 1997. Laporan Penelitian Persepsi dan harapan Maha siswa IKIP Bandung terhadap MKDU Bahasa Indonesia. Bandung: Balai Bahasa, UPI Bandung. 
Alwasilah, A. Chaedar. 1999a. Towards a Critical Pedagogy of EFL in Indonesia. Paper presented at RELC Seminar in Singapore, 18-21 April 1999.

Alwasilah, A. Chaedar. 1999b. Respon Penulis terhadap Pembaca: Studi Kasus Tulisan Mahasiswa Pascasarjana IKIP Bandung. Paper presented at PELBBA XIII, Unika Atmajaya, Jakarta, 26-27 Juli 1999.

Alwasilah, A. Chaedar. 1999c. Writing Needs More Recognition. The Jakarta Post, July 10.

Bridges, Charles W., (Ed.). 1986. Training the New Teacher of College Composition. Urbana: National Council of Teachers of English.

Brookes, Arthur and Peter Grundy.1990. Writing for Study Purposes: A Teacher's Guide to Developing Individual Writing Skills. Cambridge: Cambridge University Press.

Coleman, Hywel.1996. Shadow puppets and language lessons: Interpreting Classroom Behavior in Its Cultural Context In Coleman, (Ed.). Society and the Language Classroom. (64-85). Cambridge: Cambridge University Press. Fox, Phillipa, 1999. Ahah! A Very Confused Person's Guide to Report Writing Paper presented at RELC Seminar, 19-21 April 1999.

Informasi TPB 1999. Institut Teknologi Bandung.

Langer, Judith A. and Arthur N. Applebee. 1987. How Writing Shapes Thinking: A Study of Teaching and Leaming. Urbana: National Council of Teachers of English.

Lunsford, Ronald F. 1986. Planning for spontaneity. In Bridges, (Ed.) (95-108).

Murray, Denise E. 1992. Collabortive writing as a literacy event: implications for ESL instruction. In David Nunan, (Ed.), Collaborative Language Learning and Teaching (100-117). Cambridge: Cambridge University Press.

Ruszkiewicz, John J. 1986. The Great Commandment. In Bridges, (Ed.) (78-83).

Schenck, Mary Jane. 1986. Writing Right Off; Strategies for invention". In Bridges, (Ed.), (84-94).

Tierney, Robert J., Mark A. Carter, and Laura E. Desai. 1991. Pontfolio Assessment in the Reading-Writing Classroom. Norwood: Christopher-Gordon Publishers, Inc. 